\title{
Association between Ambient Particulate Matter 2.5 Exposure and Mortality in Patients with Hepatocellular Carcinoma
}

\author{
Chern-Horng Lee ${ }^{1}$, Sen-Yung Hsieh ${ }^{2,3}$, Wen-Hung Huang ${ }^{3,4}$, I-Kuan Wang ${ }^{5}$ and \\ Tzung-Hai Yen ${ }^{3,4, * \mathbb{D}}$ \\ 1 Division of General Internal Medicine and Geriatrics, Chang Gung Memorial Hospital, Linkou 333, Taiwan \\ 2 Department of Gastroenterology and Hepatology, Chang Gung Memorial Hospital, Linkou 333, Taiwan \\ 3 College of Medicine, Chang Gung University, Taoyuan 333, Taiwan \\ 4 Department of Nephrology and Clinical Poison Center, Chang Gung Memorial Hospital, Linkou 333, Taiwan \\ 5 Department of Nephrology, China Medical University Hospital, Taichung 404, Taiwan \\ * Correspondence: m19570@adm.cgmh.org.tw; Tel.: 886-3-3281200 (ext. 8181); Fax: 886-3-3282173
}

Received: 6 June 2019; Accepted: 6 July 2019; Published: 12 July 2019

\begin{abstract}
Air pollution is a severe public health problem in Taiwan. Moreover, Taiwan is an endemic area for hepatocellular carcinoma (HCC). This study examined the effect of particulate matter 2.5 $\left(\mathrm{PM}_{2.5}\right)$ exposure on mortality in this population. A total of 1003 patients with HCC treated at Chang Gung Memorial Hospital between 2000 and 2009 were included in this study. At the end of the analysis, $288(28.7 \%)$ patients had died. Patients with HCC living in environments with $\mathrm{PM}_{2.5}$ concentrations of $\geq 36 \mu \mathrm{g} / \mathrm{m}^{3}$ had a higher mortality rate than patients living in environments with $\mathrm{PM}_{2.5}$ concentrations of $<36 \mu \mathrm{g} / \mathrm{m}^{3}$ (36.8\% versus $\left.27.5 \%, p=0.034\right)$. The multivariate Cox regression analysis confirmed that $\mathrm{PM}_{2.5} \geq 36 \mu \mathrm{g} / \mathrm{m}^{3}$ was a significant risk factor for mortality $(1.584$ (1.162-2.160), $p=0.004)$. A nonlinear relationship was observed between the odds ratio and $\mathrm{PM}_{2.5}$. The odds ratio was 1.137 (1.015-1.264) for each increment of $5 \mu \mathrm{g} / \mathrm{m}^{3}$ in $\mathrm{PM}_{2.5}$ or 1.292 (1.030-1.598) for each increment of $10 \mu \mathrm{g} / \mathrm{m}^{3}$ in $\mathrm{PM}_{2.5}$. Therefore, patients with HCC exposed to ambient $\mathrm{PM}_{2.5}$ concentrations of $\geq 36 \mu \mathrm{g} / \mathrm{m}^{3}$ had a 1.584-fold higher risk of death than those exposed to $\mathrm{PM}_{2.5}$ concentrations of $<36 \mu \mathrm{g} / \mathrm{m}^{3}$. Further studies are warranted.
\end{abstract}

Keywords: $\mathrm{PM}_{2.5}$; particulate matter; air pollution; mortality; hepatocellular carcinoma

\section{Introduction}

In 2013, the International Agency for Research on Cancer [1] classified outdoor air pollution and particulate matter from outdoor air pollution as carcinogenic to human beings (Group 1), according to sufficient evidence of carcinogenicity in humans and experimental animals, and strong mechanistic evidence. Long-term exposure to particulate matter air pollution is a well-known risk factor for cardiopulmonary and pulmonary neoplasm mortality [2].

Few studies in the literature have reported the long-term health effects of particulate matter $2.5\left(\mathrm{PM}_{2.5}\right)$ on cancer mortality, particularly hepatocellular carcinoma (HCC), other than lung cancer. In a study, Wong et al. [3] demonstrated that $\mathrm{PM}_{2.5}$ exposure was associated with an increased risk of all-cause cancer mortality (hazard ratio (HR) 1.22 (95\% confidence interval (CI), 1.11-1.34)), and specific cancer mortality for the upper digestive tract (1.42 (1.06-1.89)), and digestive accessory organs including the liver (1.35 (1.06-1.71)) in all individuals, breast (1.80 (1.26-2.55)) in female patients, and lung (1.36 (1.05-1.77)) in male patients.

In a study conducted in Taiwan (Table 1), Pan et al. [4] reported that $\mathrm{PM}_{2.5}$ exposure was positively associated with risks of HCC, and that an elevated blood alanine aminotransferase concentration could 
be a mediator for the association between $\mathrm{PM}_{2.5}$ and HCC. In a European study, Pedersen et al. [5] demonstrated that the HR associated with each $10 \mu \mathrm{g} / \mathrm{m}^{3}$ increase in nitrogen dioxide was 1.10 (95\% CI 0.93-1.30) and 1.34 (95\% CI 0.76-2.35) for each 5- $\mu \mathrm{g} / \mathrm{m}^{3}$ increase in $\mathrm{PM}_{2.5}$. In an American study, Deng et al. [6] revealed that the all-cause mortality HR associated with a standard deviation $\left(5.0 \mu \mathrm{g} / \mathrm{m}^{3}\right)$ increase in $\mathrm{PM}_{2.5}$ was 1.18 (95\% CI 1.16-1.20): 1.31 (95\% CI 1.26-1.35) at a local stage, 1.19 (95\% CI 1.14-1.23) at a regional stage, and 1.05 (95\% CI 1.01-1.10) at a distant stage. The associations were nonlinear, with substantially larger HRs at higher exposures [5]. In another American study, VoPham et al. [7] revealed that higher concentrations of ambient $\mathrm{PM}_{2.5}$ exposure were associated with a statistically significant increased risk for HCC (HR 1.26 associated with a $10 \mu \mathrm{g} / \mathrm{m}^{3}$ increase, $95 \%$ CI $1.08-1.47)$.

Table 1. Published studies of the health effects of particulate matter air pollution on patients with HCC.

\begin{tabular}{cccccc}
\hline Study & Year & Geographic Area & HCC Cases & Air Pollution & Health Effects \\
\hline Pan et al. [4] & 2016 & Taiwan & 464 & $\mathrm{PM}_{2.5}$ & $\begin{array}{c}\text { Increased incidence } \\
\text { of HCC }\end{array}$ \\
\hline Pedersen et al. [5] & 2017 & $\begin{array}{c}\text { Denmark, Austria } \\
\text { and Italy }\end{array}$ & 279 & $\begin{array}{c}\text { Nitrogen oxides, } \\
\text { particulate matters }\end{array}$ & $\begin{array}{c}\text { Increased incidence } \\
\text { of HCC }\end{array}$ \\
\hline Deng H et al. [6] & 2017 & USA & 20,221 & $\mathrm{PM}_{2.5}$ & $\begin{array}{c}\text { Increased mortality } \\
\text { of HCC }\end{array}$ \\
\hline VoPham et al. [7] & 2018 & USA & 56,245 & $\mathrm{PM}_{2.5}$ & $\begin{array}{c}\text { Increased incidence } \\
\text { of HCC }\end{array}$ \\
\hline Current study & 2019 & Taiwan & 1003 & $\mathrm{PM}_{2.5}$ & $\begin{array}{c}\text { Increased mortality } \\
\text { of HCC }\end{array}$ \\
\hline
\end{tabular}

Note: HCC hepatocellular carcinoma; $\mathrm{PM}_{2.5}$ particulate matter 2.5 .

Nevertheless, the exact mechanisms of $\mathrm{PM}_{2.5}$-mediated HCC migration and invasion remain unclear. In a laboratory study using HCC cell lines, Zhang et al. [8] revealed that $\mathrm{PM}_{2.5}$ treatment not only stimulated the migration and invasion of HCC cells, but also increased the levels of matrix metalloproteinase (MMP)-13. Furthermore, $\mathrm{PM}_{2.5}$ increased oxidative stress by induction of intracellular reactive oxygen species formation in HCC cells. The phosphorylation of RAC-alpha serine/threonine-protein kinase (AKT) increased in response to $\mathrm{PM}_{2.5}$. High concentrations of $\mathrm{PM}_{2.5}$ decreased the proliferation of normal HL7702 hepatocyte-like cells and promoted apoptosis. Therefore, the activation of AKT by $\mathrm{PM}_{2.5}$ resulted in MMP-13 overexpression, and stimulated HCC cell migration and invasion [8]. A previous study also indicated that the carcinogenicity of $\mathrm{PM}_{2.5}$ might act through its collective effect on the suppression of DNA repair and augmentation of DNA replication errors [9].

Air pollution is a severe public health problem in Taiwan. Moreover, Taiwan is an endemic area for liver disease and HCC $[10,11]$. Therefore, the objective of this study was to examine the long-term effect of ambient $\mathrm{PM}_{2.5}$ exposure on mortality in this sensitive population.

\section{Materials and Methods}

\subsection{Ethical Statement}

This retrospective cohort study complied with the guidelines of the Declaration of Helsinki and was approved by the Medical Ethics Committee of Chang Gung Memorial Hospital, Linkou, Taiwan. Since this study included retrospective evaluation of existing data, the Institutional Review Board approval (Institutional Review Board No. 201700631B0) was acquired, but without specific informed consent from patients. However, all individual data was protected (by delinking identifying information from main data set) and accessible to researchers only. Additionally, all the data were examined namelessly. The Institutional Review Board of Chang Gung Memorial Hospital has waived the need for consent. Lastly, all primary data were gathered according to epidemiology guidelines aimed at strengthening the reporting of observational studies. 


\subsection{Inclusion and Exclusion Criteria}

A total of 1003 patients with HCC who were treated at Chang Gung Memorial Hospital between 2000 and 2009 were included in this study. Patients were grouped according to their yearly average ambient $\mathrm{PM}_{2.5}$ exposure as $<36 \mu \mathrm{g} / \mathrm{m}^{3}(N=870)$ or $\geq 36 \mu \mathrm{g} / \mathrm{m}^{3}(N=133)$. The choice of this $\mathrm{PM}_{2.5}$ cutoff value was based on the study of Pan et al. [4]. The medical records were reviewed to obtain information, such as gender, age, presence of liver cirrhosis, alcohol usage, number of tumors, largest tumor size, presence of ascites upon surgery, alpha fetoprotein, albumin, bilirubin, prothrombin time, creatinine, aspartate aminotransferase, alanine aminotransferase, date of surgical resection, date of local recurrence, living place $\mathrm{PM}_{2.5}$ concentrations, and date of the last follow-up or mortality. Patients with HCC aged less than 18 years, whose HCC was not primary, whose residential addresses were missing (without $\mathrm{PM}_{2.5}$ data), or who died within 1 month were excluded from this study.

\subsection{Determination of Ambient $P M_{2.5}$ Concentrations}

Data on ambient $\mathrm{PM}_{2.5}$ concentrations were obtained from Taiwan Air Quality Monitoring Network of Environmental Protection Administration, Executive Yuan R.O.C. of Taiwan [12]. The $\mathrm{PM}_{2.5}$ concentration, which fluctuated all the time, was averaged annually. The yearly average concentrations of $\mathrm{PM}_{2.5}$ at patients' living place were analyzed using data provided by Taiwan Air Quality Monitoring Network [12]. In Taiwan, there were 76 air quality monitoring stations, including 60 general stations, 5 industrial stations, 2 national park stations (1 station simultaneously used as a general station), 4 background stations ( 2 stations simultaneously used as general stations), 6 traffic stations and 2 other stations. The air quality monitoring data was presented real-time and archived as historical data on the web site. The $\mathrm{PM}_{2.5}$ data were normally acquired from monitoring stations in the same area. If a patient lived between two monitoring stations, the $\mathrm{PM}_{2.5}$ data from nearest station was chosen for analysis. If there was no monitoring station, the $\mathrm{PM}_{2.5}$ data from the nearest station (within $<15 \mathrm{~km}$ ) was chosen.

\subsection{Diagnosis of HCC}

HCC was diagnosed clinically by testing for alpha fetoprotein, through imaging studies such as ultrasonography, radiocontrast-enhanced triphasic dynamic computed tomography, magnetic resonance imaging, angiography, and/or documented tissue histopathology [13]. The pretreatment diagnosis of HCC was made on the basis of dynamic imaging studies and biopsy, according to the guidelines of the American Association for the Study of Liver Diseases [14]. A biopsy was performed only if the HCC was not typical or if it was equivocal.

\subsection{Barcelona Clinic Liver Cancer Staging}

The HCC was staged according to the Barcelona Clinic Liver Cancer criteria [15] .

\section{Follow-Up}

Patients were followed up with clinic visits every 2-3 months during the first 2 years and every 3-6 months thereafter. At each follow-up visit, a complete history and physical examination were performed, a blood sample was drawn to test alpha fetoprotein levels and liver function, and the liver tumor was monitored using ultrasonography and chest radiographs.

\subsection{Statistical Analysis}

Continuous variables were expressed as mean and standard deviation for the number of observations, whereas categorical variables were expressed as numbers and percentages in brackets. Student's t-test was used for quantitative variables, whereas the chi-squared or Fisher's exact test were used for categorical variables. A multivariate Cox proportional hazards model was used for the analysis of mortality risk. Survival data were analyzed using the Kaplan-Meier method, and 
their significance was tested using the log-rank test. Comparisons of survival durations were made using the log-rank test. The predictive performance was evaluated using the area under the receiver operating characteristic (ROC) curve. A P value of less than 0.05 was considered statistically significant. The data was analyzed using $\mathrm{R}$ software.

\section{Results}

Although most patients (870/1003 or $86.7 \%$ ) were exposed to ambient $\mathrm{PM}_{2.5}$ concentrations of $<36 \mu \mathrm{g} / \mathrm{m}^{3}$, some patients (133/1003 or $13.3 \%$ ) were exposed to ambient $\mathrm{PM}_{2.5}$ concentrations of $\geq 36 \mu \mathrm{g} / \mathrm{m}^{3}$ (Table 2). The patients with HCC were aged $61.1 \pm 12.1$ years, and most were male $(73.0 \%)$. Hepatitis B virus and hepatitis C virus were observed in $56.3 \%$ and $38.6 \%$ of the patients, respectively. The majority of patients were diagnosed as having HCC at an early stage as follows: stage 0: 14.0\%; stage A: $34.1 \%$; stage B: $32.7 \%$; stage C: $14.7 \%$; and stage D: $4.6 \%$. Furthermore, the liver cirrhosis scores were as follows: Child-Pugh 0: 28.6\%; Child-Pugh A: 49.5\%; Child-Pugh B: 16.8\%; and Child-Pugh C: $5.1 \%$. Patients were followed up for $3.32 \pm 2.97$ years. At the end of the analysis, $288(28.7 \%)$ patients had died. Patients with HCC living in an environment with ambient $\mathrm{PM}_{2.5}$ concentrations of $\geq 36 \mu \mathrm{g} / \mathrm{m}^{3}$ had a higher mortality rate than patients living in an environment with ambient $\mathrm{PM}_{2.5}$ concentrations of $<36 \mu \mathrm{g} / \mathrm{m}^{3}(36.8 \%$ versus $27.5 \%, p=0.034)$.

Table 2. Baseline characteristics of patients with $\operatorname{HCC}(N=1003)$.

\begin{tabular}{|c|c|c|c|c|}
\hline Variable & Total $(N=1003)$ & $\begin{array}{c}\mathrm{PM}_{2.5}<36 \mu \mathrm{g} / \mathrm{m}^{3} \\
(N=870)\end{array}$ & $\begin{array}{c}\mathrm{PM}_{2.5} \geq 36 \mu \mathrm{g} / \mathrm{m}^{3} \\
(N=133)\end{array}$ & $p$-Value \\
\hline Age (year) & $61.05(12.07)$ & $61.22(12.02)$ & $59.89(12.36)$ & 0.235 \\
\hline Male gender & $732(73.0)$ & $631(72.5)$ & $101(75.9)$ & 0.471 \\
\hline Diabetes mellitus & $249(24.8)$ & $219(25.2)$ & $30(22.6)$ & 0.587 \\
\hline Hypertension & $245(24.4)$ & $212(24.4)$ & $33(24.8)$ & 0.998 \\
\hline Hepatitis B virus surface antigen & $565(56.3)$ & $483(55.5)$ & $82(61.7)$ & 0.217 \\
\hline Antibodies to hepatitis $C$ virus & $387(38.6)$ & $334(38.4)$ & $53(39.8)$ & 0.821 \\
\hline Alcoholic consumption & $157(15.7)$ & $138(15.9)$ & $19(14.3)$ & 0.735 \\
\hline Tumor number & $1.94(1.46)$ & $1.96(1.48)$ & $1.81(1.33)$ & 0.245 \\
\hline Tumor size $(\mathrm{cm})$ & $4.41(3.40)$ & $4.39(3.41)$ & $4.54(3.33)$ & 0.637 \\
\hline Tumor, node, metastases staging & & & & 0.253 \\
\hline Stage 0 & $136(13.6)$ & $124(14.3)$ & $12(9.0)$ & \\
\hline Stage 1 & $402(40.1)$ & $346(39.8)$ & $56(42.1)$ & \\
\hline Stage 2 & $307(30.6)$ & $268(30.8)$ & $39(29.3)$ & \\
\hline Stage 3 & $143(14.3)$ & $118(13.6)$ & $25(18.8)$ & \\
\hline Stage 4 & $15(1.5)$ & $14(1.6)$ & $1(0.8)$ & \\
\hline Barcelona Clinic Liver Cancer staging & & & & 0.492 \\
\hline Stage 0 & $140(14.0)$ & $123(14.1)$ & $17(12.8)$ & \\
\hline Stage A & $342(34.1)$ & $302(34.7)$ & $40(30.1)$ & \\
\hline Stage B & $328(32.7)$ & $279(32.1)$ & $49(36.8)$ & \\
\hline Stage C & $147(14.7)$ & $129(14.8)$ & $18(13.5)$ & \\
\hline Stage D & $46(4.6)$ & $37(4.3)$ & $9(6.8)$ & \\
\hline Child-Pugh score & & & & 0.24 \\
\hline Child 0 & $287(28.6)$ & $249(28.6)$ & $38(28.6)$ & \\
\hline Child A & $496(49.5)$ & $437(50.2)$ & $59(44.4)$ & \\
\hline Child B & $169(16.8)$ & $144(16.6)$ & $25(18.8)$ & \\
\hline Child C & $51(5.1)$ & $40(4.6)$ & $11(8.3)$ & \\
\hline
\end{tabular}


Table 2. Cont

\begin{tabular}{|c|c|c|c|c|}
\hline Variable & Total $(N=1003)$ & $\begin{array}{c}\mathrm{PM}_{2.5}<36 \mu \mathrm{g} / \mathrm{m}^{3} \\
(N=870)\end{array}$ & $\begin{array}{c}\mathrm{PM}_{2.5} \geq 36 \mu \mathrm{g} / \mathrm{m}^{3} \\
(N=133)\end{array}$ & $p$-Value \\
\hline Aspartate aminotransferase (IU/L) & $76.78(91.83)$ & $75.23(87.67)$ & $86.93(115.30)$ & 0.171 \\
\hline Alanine aminotransferase (IU/L) & $68.64(94.19)$ & $68.13(86.50)$ & $71.98(134.46)$ & 0.66 \\
\hline Total bilirubin (mg/dL) & $1.51(2.25)$ & $1.50(2.22)$ & $1.58(2.44)$ & 0.702 \\
\hline Albumin (g/dL) & $3.70(3.08)$ & $3.61(0.64)$ & $4.30(8.30)$ & $0.017^{*}$ \\
\hline Alkaline phosphatase (U/L) & $121.21(89.32)$ & $120.74(91.72)$ & $124.28(71.87)$ & 0.671 \\
\hline Blood urea nitrogen (mg/dL) & $18.60(16.23)$ & $18.65(16.96)$ & $18.33(10.36)$ & 0.834 \\
\hline Creatinine (mg/dL) & $1.36(1.64)$ & $1.37(1.69)$ & $1.31(1.24)$ & 0.703 \\
\hline Sodium (meq/L) & $140.57(42.22)$ & $140.67(45.13)$ & $139.92(10.97)$ & 0.849 \\
\hline White Blood Cell $(1000 / \mu \mathrm{L})$ & $4.65(2.39)$ & $4.65(2.39)$ & $4.65(2.39)$ & 0.394 \\
\hline Hemogloblin (mg/dL) & $12.19(2.44)$ & $12.18(2.48)$ & $12.26(2.18)$ & 0.718 \\
\hline Hematocrit (\%) & $36.38(7.03)$ & $36.35(7.14)$ & $36.61(6.27)$ & 0.687 \\
\hline Platelet $\left(10^{3} / \mu \mathrm{L}\right)$ & $144.31(85.00)$ & $142.18(80.07)$ & $158.19(111.41)$ & $0.043^{*}$ \\
\hline Prolong prothrombin time (second) & $2.23(4.87)$ & $2.17(4.01)$ & $2.63(8.57)$ & 0.31 \\
\hline Alpha fetoprotein (ng/mL) & $\begin{array}{c}8332.45 \\
(82,445.91)\end{array}$ & $\begin{array}{c}9452.76 \\
(88,468.89)\end{array}$ & $\begin{array}{c}1004.17 \\
(3072.30)\end{array}$ & 0.271 \\
\hline First treatment method & & & & 0.604 \\
\hline Transarterial chemoembolization & $444(44.3)$ & $378(43.4)$ & $66(49.6)$ & \\
\hline Radiofrequency ablation & $152(15.2)$ & $136(15.6)$ & $16(12.0)$ & \\
\hline Resection & $260(25.9)$ & $225(25.9)$ & $35(26.3)$ & \\
\hline Supportive & $108(10.8)$ & $96(11.0)$ & $12(9.0)$ & \\
\hline Radiotherapy or Chemotherapy & $39(3.9)$ & $35(4.0)$ & $4(3.0)$ & \\
\hline Macrovascular invasion & 135 (13.5) & $118(13.6)$ & $17(12.8)$ & 0.913 \\
\hline Follow-up duration (year) & $3.32(2.97)$ & $3.38(3.01)$ & $2.91(2.69)$ & 0.086 \\
\hline Mortality & $288(28.7)$ & $239(27.5)$ & $49(36.8)$ & $0.034 *$ \\
\hline
\end{tabular}

Note: Continuous variables were expressed as mean and standard deviation for the number of observations, whereas categorical variables were expressed as numbers and percentages in brackets. ${ }^{*} p<0.05,{ }^{* *} p<0.01,{ }^{* * *} p<0.001$; HCC: hepatocellular carcinoma; SD: standard deviation.

As presented in Tables 3 and 4, the multivariate Cox regression analysis revealed that $\mathrm{PM}_{2.5} \geq 36 \mu \mathrm{g} / \mathrm{m}^{3}(p=0.004)$, Child-Pugh score $(p<0.001)$, albumin $(p<0.001)$, macrovascular invasion $(p<0.001)$, tumor number $(p<0.001)$, and tumor size $(p<0.001)$ were significant risk factors for mortality.

Table 3. Univariate Cox regression analysis of mortality $(N=1003)$.

\begin{tabular}{|c|c|c|}
\hline Variable & $\begin{array}{l}\text { Univariate Analysis Odds Ratio } \\
\text { (95\% Confidence Interval) }\end{array}$ & $p$-Value \\
\hline $\mathrm{PM}_{2.5} \geq 36 \mu \mathrm{g} / \mathrm{m}^{3}$ & $1.528(1.123-2.079)$ & $0.007^{* *}$ \\
\hline Age (year) & $1.001(0.991-1.011)$ & 0.873 \\
\hline Gender, male & $1.154(0.882-1.511)$ & 0.296 \\
\hline Diabetes mellitus, yes & $1.059(0.808-1.387)$ & 0.68 \\
\hline Hypertension, yes & $0.904(0.689-1.186)$ & 0.47 \\
\hline Hepatitis B virus surface antigen, yes & $1.126(0.89-1.425)$ & 0.325 \\
\hline Antibodies to hepatitis $C$ virus, yes & $0.866(0.682-1.101)$ & 0.239 \\
\hline Alcoholic Consumption, yes & $1.398(1.031-1.895)$ & $0.03 *$ \\
\hline Aspartate aminotransferase (IU/L) & $1.002(1.002-1.002)$ & $<0.001^{* * *}$ \\
\hline
\end{tabular}


Table 3. Cont

\begin{tabular}{|c|c|c|}
\hline Variable & $\begin{array}{l}\text { Univariate Analysis Odds Ratio } \\
(95 \% \text { Confidence Interval) }\end{array}$ & $p$-Value \\
\hline Alanine aminotransferase (IU/L) & $1(0.998-1.002)$ & 0.661 \\
\hline Total bilirubin (mg/dL) & $1.071(1.031-1.111)$ & $<0.001^{* * *}$ \\
\hline Albumin (g/dL) & $0.578(0.483-0.69)$ & $<0.001^{* * *}$ \\
\hline Alkaline phosphatase (U/L) & $1.003(1.003-1.003)$ & $<0.001^{* * *}$ \\
\hline Blood urea nitrogen (mg/dL) & $1.008(1-1.016)$ & $0.027^{*}$ \\
\hline Creatinine (mg/dL) & $1.019(0.958-1.082)$ & 0.553 \\
\hline Sodium (meq/L) & $0.989(0.975-1.003)$ & 0.087 \\
\hline White Blood Cell $(1000 / \mu \mathrm{L})$ & $1.002(0.996-1.008)$ & 0.367 \\
\hline Hemogloblin (mg/dL) & $0.932(0.89-0.974)$ & $0.002 * *$ \\
\hline Hematocrit (\%) & $0.976(0.961-0.992)$ & $0.002 * *$ \\
\hline Platelet $\left(10^{3} / \mu \mathrm{L}\right)$ & $1(0.998-1.002)$ & 0.601 \\
\hline Prolong prothrombin time (second) & $1.013(0.993-1.034)$ & 0.19 \\
\hline Alpha fetoprotein (ng/mL) & $1(1-1)$ & 0.284 \\
\hline Tumor number & $1.227(1.143-1.318)$ & $<0.001 * * *$ \\
\hline Tumor size $(\mathrm{cm})$ & $1.102(1.07-1.134)$ & $<0.001^{* * *}$ \\
\hline Macrovascular invasion & $1.956(1.461-2.62)$ & $<0.001 * * *$ \\
\hline $\begin{array}{l}\text { Tumor, node, metastases stage } \\
\text { ( } 0 \text { as reference })\end{array}$ & & $<0.001^{* * *}$ \\
\hline Stage 1 & $1.109(0.74-1.66)$ & 0.616 \\
\hline Stage 2 & $1.558(1.031-2.351)$ & $0.034^{*}$ \\
\hline Stage 3 & $2.584(1.639-4.071)$ & $<0.001 * * *$ \\
\hline Stage 4 & $6.088(2.34-15.831)$ & $<0.001 * * *$ \\
\hline $\begin{array}{l}\text { Barcelona Clinic Liver Cancer stage } \\
\text { (0 as reference) }\end{array}$ & & $<0.001 * * *$ \\
\hline Stage A & $1.096(0.734-1.634)$ & 0.654 \\
\hline Stage B & $1.772(1.2-2.617)$ & $0.004^{* *}$ \\
\hline Stage C & $3.247(2.094-5.038)$ & $<0.001^{* * *}$ \\
\hline Stage D & $3.256(1.87-5.675)$ & $<0.001 * * *$ \\
\hline $\begin{array}{l}\text { Child-Pugh score } \\
\text { (0 as reference) }\end{array}$ & & $<0.001 * * *$ \\
\hline Child A & $0.89(0.668-1.184)$ & 0.424 \\
\hline Child B & $2.262(1.624-3.149)$ & $<0.001 * * *$ \\
\hline Child C & $2.683(1.68-4.284)$ & $<0.001 * * *$ \\
\hline $\begin{array}{l}\text { First treatment method } \\
\text { (supportive as reference) }\end{array}$ & & $<0.001 * * *$ \\
\hline Transarterial chemoembolization & $0.418(0.289-0.605)$ & $<0.001^{* * *}$ \\
\hline Radiofrequency ablation & $0.278(0.176-0.439)$ & $<0.001^{* * *}$ \\
\hline Resection & $0.229(0.152-0.347)$ & $<0.001^{* * *}$ \\
\hline Radiotherapy or Chemotherapy & $0.927(0.507-1.695)$ & 0.806 \\
\hline
\end{tabular}

Note: ${ }^{*} p<0.05,{ }^{* *} p<0.01,{ }^{* * *} p<0.001 ; \mathrm{PM}_{2.5}$ : particulate matter 2.5 . 
Table 4. Multivariate Cox regression analysis of mortality $(N=1003)$.

\begin{tabular}{ccc}
\hline Variable & Odds Ratio (95\% Confidence Interval) & $p$-Value \\
\hline $\mathrm{PM}_{2.5} \geq 36 \mu \mathrm{g} / \mathrm{m}^{3}$ & $1.584(1.162-2.160)$ & $0.004^{* *}$ \\
\hline Child-Pugh score $(0$ as reference) & & $<0.001^{* * *}$ \\
\hline Child A & $0.97(0.723-1.302)$ & 0.84 \\
\hline Child B & $2.075(1.458-2.954)$ & $<0.001^{* * *}$ \\
\hline Child C & $2.741(1.652-4.545)$ & $<0.001^{* * *}$ \\
\hline Albumin & $0.679(0.558-0.826)$ & $<0.001^{* * *}$ \\
\hline Macrovascular invasion & $2.323(1.655-3.261)$ & $<0.001^{* * *}$ \\
\hline Tumor number & $1.195(1.111-1.285)$ & $<0.001^{* * *}$ \\
\hline Tumor size $(\mathrm{cm})$ & $1.085(1.048-1.124)$ & $<0.001^{* * *}$ \\
\hline Note: ${ }^{* *} p<0.01, * * * p<0.001 ; \mathrm{PM}_{2.5}:$ particulate matter 2.5. &
\end{tabular}

In a ROC curve analysis, the area under the curve was $0.764,0.714$, and 0.705 in the first, third, and fifth year, respectively (Figure 1).

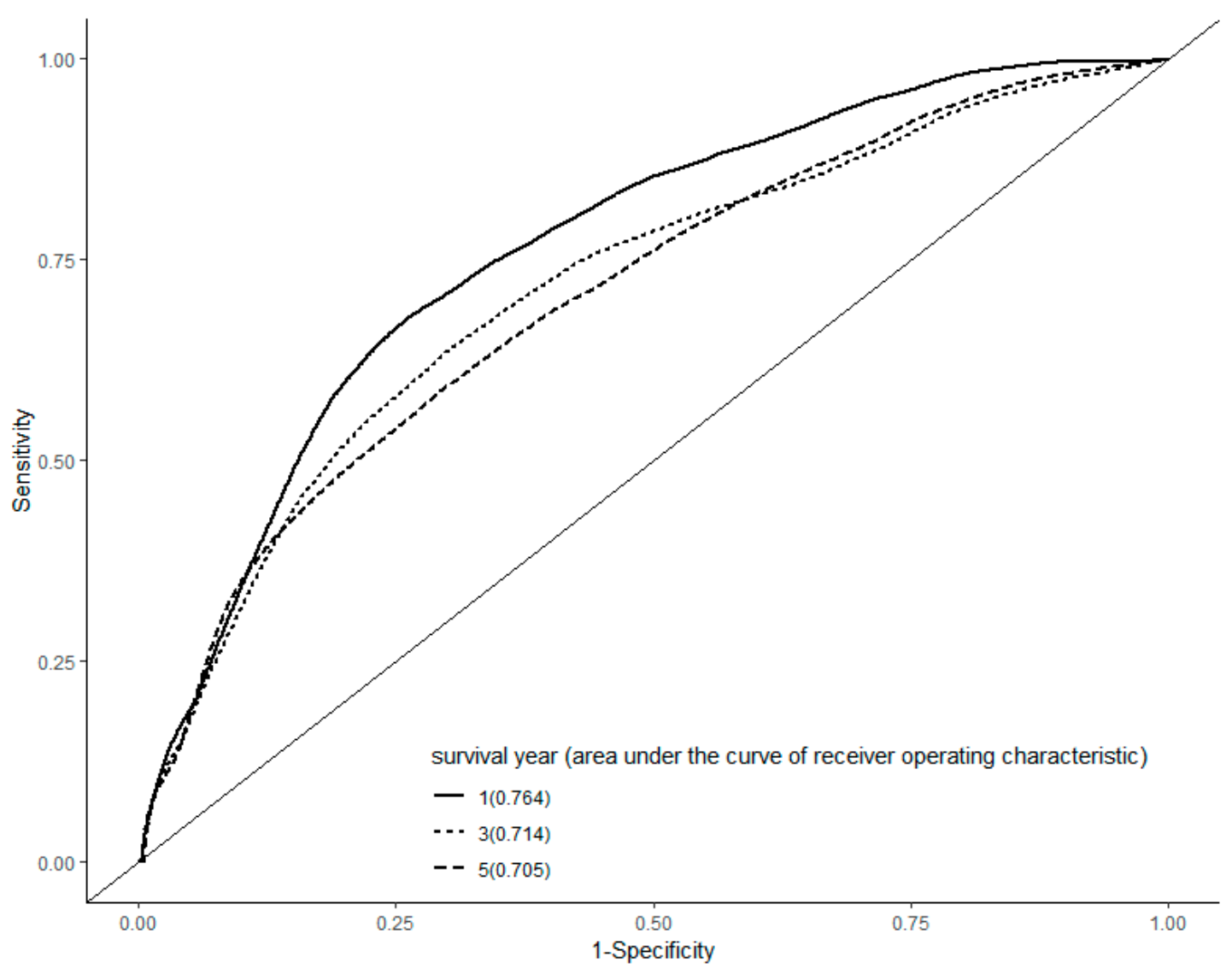

Figure 1. Receiver operating characteristic curve analysis. The area under the curve was $0.764,0.714$, and 0.705 in the first, third, and fifth year after the diagnosis of hepatocellular carcinoma, respectively.

The Kaplan-Meier survival analysis also revealed that patients living in environments with $\mathrm{PM}_{2.5}$ concentrations of $\geq 36 \mu \mathrm{g} / \mathrm{m}^{3}$ had a lower cumulative survival than patients living in environments with $\mathrm{PM}_{2.5}$ concentrations of $<36 \mu \mathrm{g} / \mathrm{m}^{3}$ (log-rank test, $p=0.0065$, Figure 2). 


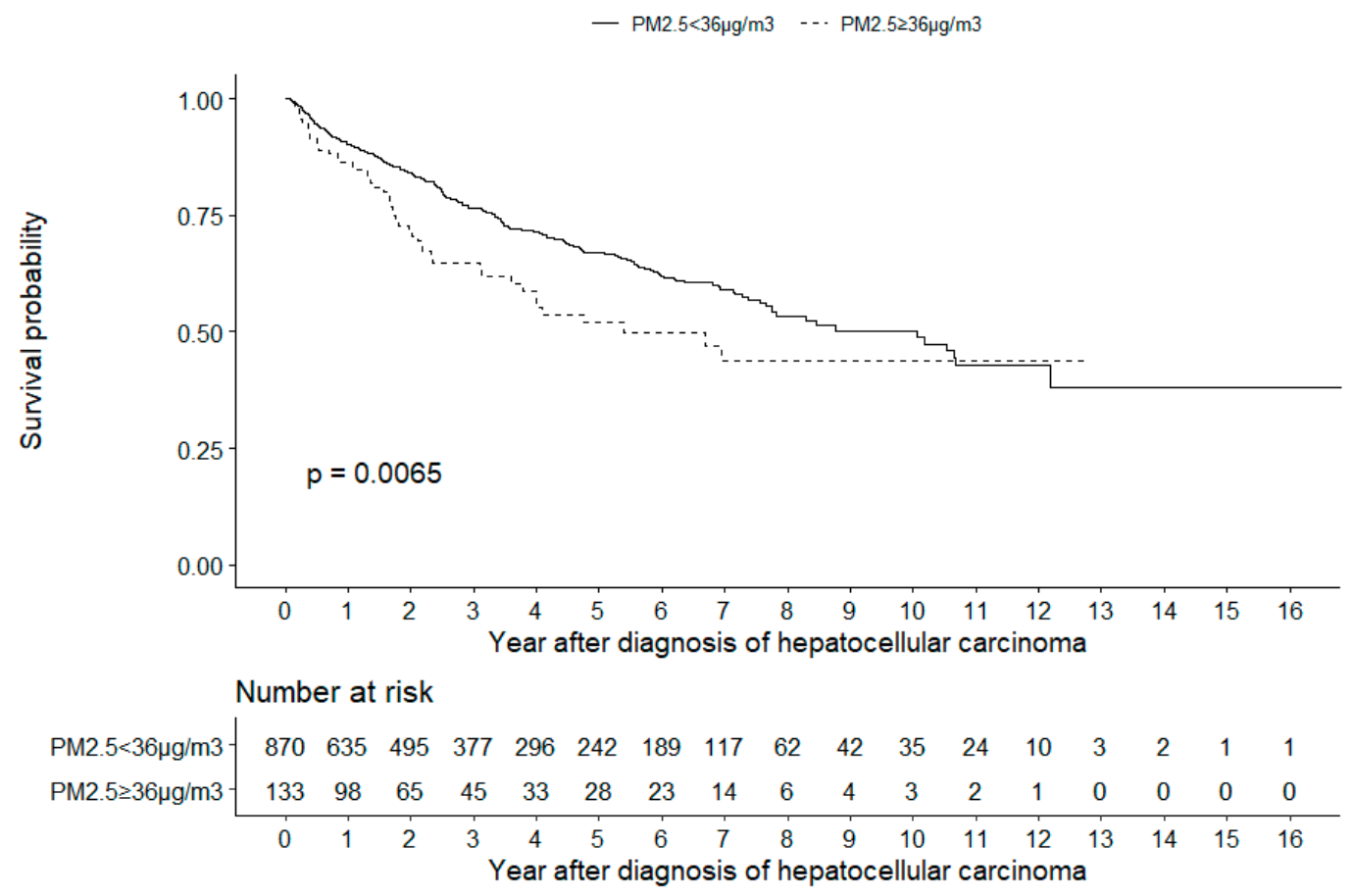

Figure 2. Kaplan-Meier analysis. The analysis revealed that patients with hepatocellular carcinoma living in environments with $\mathrm{PM}_{2.5}$ concentrations of $\geq 36 \mu \mathrm{g} / \mathrm{m}^{3}$ had a lower cumulative survival than patients living in environments with $\mathrm{PM}_{2.5}$ concentrations of $<36 \mu \mathrm{g} / \mathrm{m}^{3}$ (log-rank test, $\left.\mathrm{P}=0.0065\right)$.

As illustrated in Figure 3, a nonlinear relationship was observed between the odds ratio and $\mathrm{PM}_{2.5}$. The odds ratio (95\% CI) was 1.137 (1.015-1.264) for each increment of $5 \mu \mathrm{g} / \mathrm{m}^{3}$ in $\mathrm{PM}_{2.5}$ or 1.292 (1.030-1.598) for each increment of $10 \mu \mathrm{g} / \mathrm{m}^{3}$ in $\mathrm{PM}_{2.5}$.

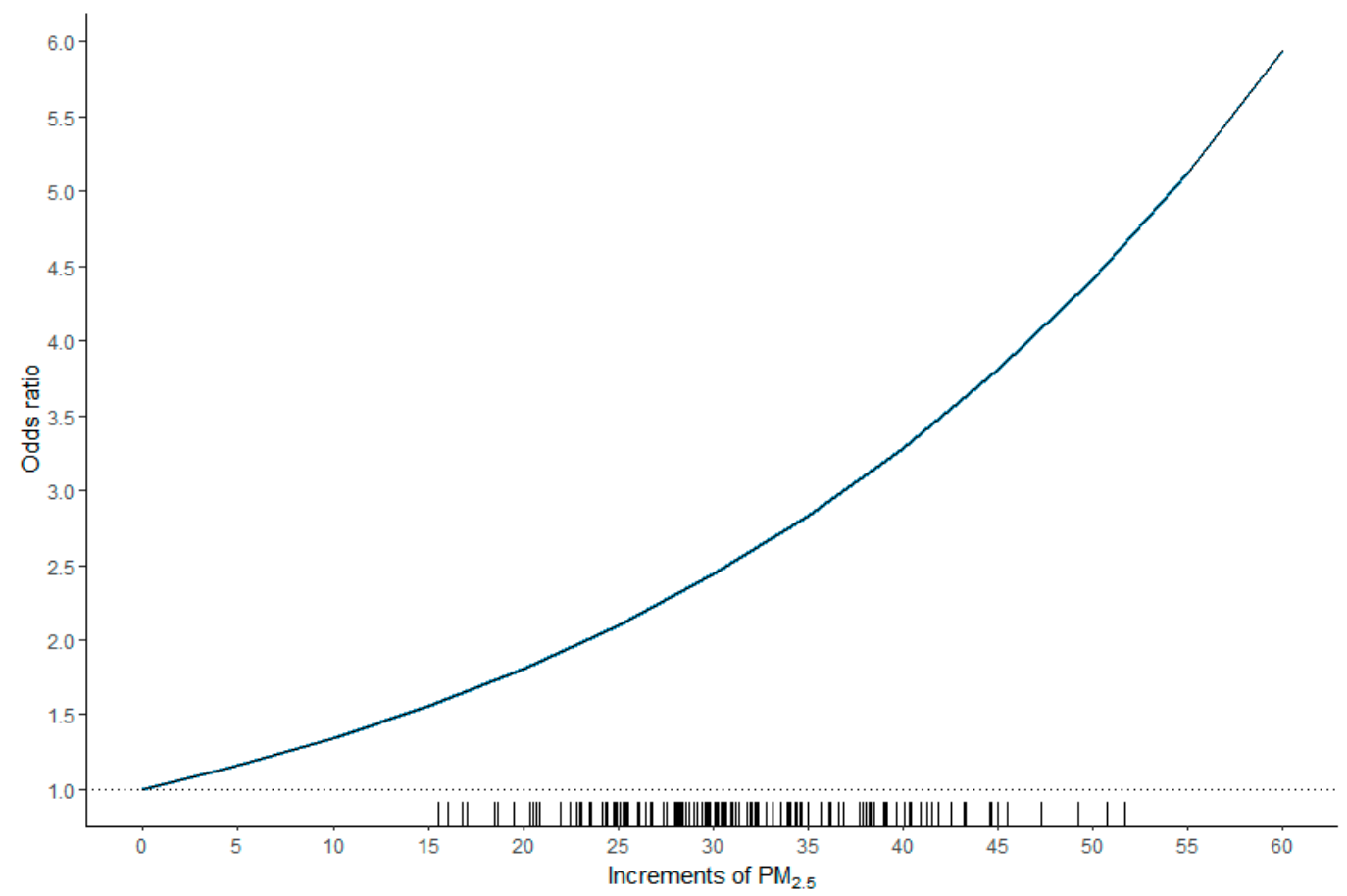

Figure 3. Plot of the odds ratio versus increments of $\mathrm{PM}_{2.5}$. A nonlinear relationship was observed between the odds ratio and $\mathrm{PM}_{2.5}$. The odds ratio (95\% confidence interval) was 1.137 (1.015-1.264) for each increment of $5 \mu \mathrm{g} / \mathrm{m}^{3}$ in $\mathrm{PM}_{2.5}$ or 1.292 (1.030-1.598) for each increment of $10 \mu \mathrm{g} / \mathrm{m}^{3}$ in $\mathrm{PM}_{2.5}$. 


\section{Discussion}

As presented in Table 1, the literature on the health effects of $\mathrm{PM}_{2.5}$ on patients with HCC has been limited. Not only did the present study investigate a large patient population $(N=1003)$, but it also indicated that $\mathrm{PM}_{2.5} \geq 36 \mu \mathrm{g} / \mathrm{m}^{3}$ [1.584 (1.162-2.160), $\left.p=0.004\right]$ was a significant risk factor for mortality. The patients with HCC exposed to ambient $\mathrm{PM}_{2.5}$ concentrations of $\geq 36 \mu \mathrm{g} / \mathrm{m}^{3}$ had a 1.584-fold higher risk of death than those exposed to $\mathrm{PM}_{2.5}$ concentrations of $<36 \mu \mathrm{g} / \mathrm{m}^{3}$.

The positive association between ambient $\mathrm{PM}_{2.5}$ exposure and mortality is consistent with the data reported by other groups (Table 1). Unlike in the study of Pan et al. [4], the blood alanine aminotransferase concentration was not a significant predictor for mortality according to the Cox regression analysis (Tables 3 and 4). Although the mean blood concentrations of alanine aminotransferase were slightly higher in patients living in environments with $\mathrm{PM}_{2.5}$ concentrations of $\geq 36 \mu \mathrm{g} / \mathrm{m}^{3}$ than in those living in environments with $\mathrm{PM}_{2.5}$ concentrations of $<36 \mu \mathrm{g} / \mathrm{m}^{3}$, the difference was not significant (71.98 (134.46) versus 68.13 (86.50), $p=0.66$, Table 2).

According to Wong et al. [3], $\mathrm{PM}_{2.5}$-associated mortality could possibly be [16] a result of oxidative stress induced by $\mathrm{PM}_{2.5}$ on epithelial cells creating reactive oxygen species that can injure DNA, proteins, and lipids. Another explanation is [17] that $\mathrm{PM}_{2.5}$-induced inflammation leads to the production of chemokines and cytokines that activate angiogenesis, enabling the epithelial invasion of metastatic cells and the persistence of attacking cells in distant tissues.

The multivariate Cox regression model revealed that $\mathrm{PM}_{2.5} \geq 36 \mu \mathrm{g} / \mathrm{m}^{3}(p=0.004)$, Child-Pugh score $(p<0.001)$, albumin $(p<0.001)$, macrovascular invasion $(p<0.001)$, tumor number $(p<0.001)$, and tumor size $(p<0.001)$ were critical risk factors for mortality. The positive association between the Child-Pugh score and mortality as well as the negative association between the blood albumin level and mortality were reasonable because both variables reflect the status of hepatic reserve. The Child-Pugh score has been widely used to assess the severity of liver dysfunction in clinical practice [18].

In a pioneering study, Deng et al. [6] reported that exposure to elevated $\mathrm{PM}_{2.5}$ after the diagnosis of HCC shortens patient survival, with larger effects at higher concentrations. Notably, the study demonstrated that the associations between $\mathrm{PM}_{2.5}$ exposure and mortality were nonlinear, with substantially larger risks at higher exposures. Similarly, a nonlinear relationship between odds ratio and $\mathrm{PM}_{2.5}$, with larger risks at higher exposures, was also observed in our study. The odds ratio was 1.137 (1.015-1.264) for each increment of $5 \mu \mathrm{g} / \mathrm{m}^{3}$ in $\mathrm{PM}_{2.5}$ or 1.292 (1.030-1.598) for each increment of $10 \mu \mathrm{g} / \mathrm{m}^{3}$ in $\mathrm{PM}_{2.5}$.

A positive association was observed between mortality and macrovascular invasion $(p<0.001)$, tumor number $(p<0.001)$, and tumor size $(p<0.001)$. In a study of 104 patients with HCC Barcelona Clinic Liver Cancer stage B after hepatectomy [19], microvessel invasion, lymph node metastasis, and multiple lesions were risk factors for mortality $(p<0.05)$. In another study [20], the amount of vascular invasion based on the presence of microvascular invasion and gross invasion was associated with tumor recurrence and mortality. HCC growing larger than $3 \mathrm{~cm}$ in diameter is considered [21] a key turning point in the transformation of a tumor from having relatively benign features to more aggressive behaviors. Clinical evidence [22] also indicated that patients with HCC with tumors measuring $>3 \mathrm{~cm}$ in diameter have an increased risk of microvascular invasion and satellite nodules. Furthermore, Asaoka et al. [23] reported that the median survival time after the development of vascular invasion was only 6 months. In a retrospective study, Montasser et al. [24] surveyed 105 patients with HCC, representing 138 lesions, who underwent radiofrequency ablation and were followed up for at least 1 year. Intrahepatic distant recurrence developed in $62(59.0 \%)$ of the patients. Both a tumor size of $>2.8 \mathrm{~cm}$ and multinodular tumors were significant risk factors for intrahepatic distant recurrence within 1 year. In a study of 554 patients with HCC, Tsuchiya et al. [25] reported that a higher rate of recurrence was noted in patients who had a larger tumor size $(>2 \mathrm{~cm})$ and/or a higher serum alpha fetoprotein concentration $(>100 \mathrm{ng} / \mathrm{mL})$ after radiofrequency ablation. 


\section{Conclusions}

In conclusion, this retrospective cohort study revealed that patients with HCC living in environments with $\mathrm{PM}_{2.5}$ concentrations of $\geq 36 \mu \mathrm{g} / \mathrm{m}^{3}$ had a higher mortality rate than patients living in environments with $\mathrm{PM}_{2.5}$ concentrations of $<36 \mu \mathrm{g} / \mathrm{m}^{3}(p=0.034)$, and $\mathrm{PM}_{2.5} \geq 36 \mu \mathrm{g} / \mathrm{m}^{3}$ was a significant risk factor for mortality $(p=0.004)$. The patients with HCC living in environments with $\mathrm{PM}_{2.5}$ concentrations of $\geq 36 \mu \mathrm{g} / \mathrm{m}^{3}$ had a 1.584-fold higher risk of death than those living in environments with $\mathrm{PM}_{2.5}$ concentrations of $<36 \mu \mathrm{g} / \mathrm{m}^{3}$. A nonlinear relationship was observed between the odds ratio and $\mathrm{PM}_{2.5}$. The odds ratio was 1.137 (1.015-1.264) for each increment of $5 \mu \mathrm{g} / \mathrm{m}^{3}$ in $\mathrm{PM}_{2.5}$ or 1.292 (1.030-1.598) for each increment of $10 \mu \mathrm{g} / \mathrm{m}^{3}$ in $\mathrm{PM}_{2.5}$. The limitations of this study include its retrospective nature, short follow-up duration, and small sample size. Further studies are warranted.

Author Contributions: Conceptualization and manuscript writing: C.H.L. and T.H.Y.; patient management: S.Y.H.; data analysis: W.H.H. and I.K.W.; supervision: T.H.Y.

Funding: C.H.L. and T.H.Y. are funded by research grants (CMRPG3H0801, CORPG3H0501 and CORPG3H0491) from Chang Gung Memorial Hospital.

Conflicts of Interest: The authors declare no conflict of interest.

\section{References}

1. Loomis, D.; Grosse, Y.; Lauby-Secretan, B.; El Ghissassi, F.; Bouvard, V.; Benbrahim-Tallaa, L.; Guha, N.; Baan, R.; Mattock, H.; Straif, K. International Agency for Research on Cancer Monograph Working Group, I., The carcinogenicity of outdoor air pollution. Lancet Oncol. 2013, 14, 1262-1263. [CrossRef]

2. Pope, C.A., 3rd; Burnett, R.T.; Thun, M.J.; Calle, E.E.; Krewski, D.; Ito, K.; Thurston, G.D. Lung cancer, cardiopulmonary mortality and long-term exposure to fine particulate air pollution. JAMA 2002, 287, 1132-1141. [CrossRef] [PubMed]

3. Wong, C.M.; Tsang, H.; Lai, H.K.; Thomas, G.N.; Lam, K.B.; Chan, K.P.; Zheng, Q.; Ayres, J.G.; Lee, S.Y.; Lam, T.H.; et al. Cancer Mortality Risks from Long-term Exposure to Ambient Fine Particle. Cancer Epidemiol. Prev. Biomark. 2016, 25, 839-845. [CrossRef] [PubMed]

4. Pan, W.C.; Wu, C.D.; Chen, M.J.; Huang, Y.T.; Chen, C.J.; Su, H.J.; Yang, H.I. Fine Particle Pollution, Alanine Transaminase, and Liver Cancer: A Taiwanese Prospective Cohort Study (REVEAL-HBV). J. Natl. Cancer. Inst. 2016, 108, 3. [CrossRef] [PubMed]

5. Pedersen, M.; Andersen, Z.J.; Stafoggia, M.; Weinmayr, G.; Galassi, C.; Sorensen, M.; Eriksen, K.T.; Tjonneland, A.; Loft, S.; Jaensch, A.; et al. Ambient air pollution and primary liver cancer incidence in four European cohorts within the ESCAPE project. Environ. Res. 2017, 154, 226-233. [CrossRef]

6. Deng, H.; Eckel, S.P.; Liu, L.; Lurmann, F.W.; Cockburn, M.G.; Gilliland, F.D. Particulate matter air pollution and liver cancer survival. Int. J. Cancer 2017, 141, 744-749. [CrossRef]

7. VoPham, T.; Bertrand, K.A.; Tamimi, R.M.; Laden, F.; Hart, J.E. Ambient PM 2.5 air pollution exposure and hepatocellular carcinoma incidence in the United States. Cancer Causes Control. 2018, 29, 563-572. [CrossRef]

8. Zhang, Q.; Luo, Q.; Yuan, X.; Chai, L.; Li, D.; Liu, J.; Lv, Z. Atmospheric particulate matter2.5 promotes the migration and invasion of hepatocellular carcinoma cells. Oncol. Lett. 2017, 13, 3445-3450. [CrossRef]

9. Mehta, M.; Chen, L.C.; Gordon, T.; Rom, W.; Tang, M.S. Particulate matter inhibits DNA repair and enhances mutagenesis. Mutat. Res. 2008, 657, 116-121. [CrossRef]

10. Lee, C.H.; Hsieh, S.Y.; Chang, C.C.; Wang, I.K.; Huang, W.H.; Weng, C.H.; Hsu, C.W.; Yen, T.H. Hepatocellular carcinoma in hemodialysis patients. Oncotarget 2017, 8, 73154-73161. [CrossRef]

11. Lee, C.H.; Chang, C.J.; Lin, Y.J.; Yen, C.L.; Shen, C.H.; Cheng, Y.T.; Lin, C.C.; Hsieh, S.Y. Nomogram predicting extrahepatic metastasis of hepatocellular carcinoma based on commonly available clinical data. JGH Open 2019, 3, 38-45. [CrossRef] [PubMed]

12. Taiwan Air Quality Monitoring Newwork. Available online: https://taqm.epa.gov.tw/taqm/en/ YearlyDataDownload.aspx (accessed on 12 July 2019).

13. Shiina, S.; Tateishi, R.; Imamura, M.; Teratani, T.; Koike, Y.; Sato, S.; Obi, S.; Kanai, F.; Kato, N.; Yoshida, H.; et al. Percutaneous ethanol injection for hepatocellular carcinoma: 20-year outcome and prognostic factors. Liver Int. 2012, 32, 1434-1442. [CrossRef] [PubMed] 
14. Bruix, J.; Sherman, M. American Association for the Study of Liver, D., Management of hepatocellular carcinoma: An update. Hepatology 2011, 53, 1020-1022. [CrossRef] [PubMed]

15. Llovet, J.M.; Bru, C.; Bruix, J. Prognosis of hepatocellular carcinoma: The BCLC staging classification. Semin Liver Dis. 1999, 19, 329-338. [CrossRef] [PubMed]

16. Risom, L.; Moller, P.; Loft, S. Oxidative stress-induced DNA damage by particulate air pollution. Mutat. Res. 2005, 592, 119-137. [CrossRef] [PubMed]

17. Mantovani, A.; Allavena, P.; Sica, A.; Balkwill, F. Cancer-related inflammation. Nature 2008, 454, 436-444. [CrossRef]

18. Peng, Y.; Qi, X.; Guo, X. Child-Pugh Versus MELD Score for the Assessment of Prognosis in Liver Cirrhosis: A Systematic Review and Meta-Analysis of Observational Studies. Medicine 2016, 95, e2877. [CrossRef]

19. Qian, H.; Wei, M.; Qiu, H.; Wu, J.; Liu, B.; Lyu, A.; Liu, Q.; Li, C.; Leng, J.; Zhang, J.; et al. A scoring system for prediction of early recurrence after liver resection for Barcelona Clinic Liver Cancer stage B hepatocellular carcinoma. Chin. Med. J. (Engl.) 2014, 127, 4171-4176.

20. Park, Y.K.; Song, S.K.; Kim, B.W.; Park, S.K.; Chung, C.W.; Wang, H.J. Prognostic significance of microvascular invasion in tumor stage for hepatocellular carcinoma. World J. Surg. Oncol. 2017, 15, 225. [CrossRef]

21. Cong, W.M.; Wu, M.C. Small hepatocellular carcinoma: Current and future approaches. Hepatol. Int. 2013, 7, 805-812. [CrossRef]

22. Lu, X.Y.; Xi, T.; Lau, W.Y.; Dong, H.; Xian, Z.H.; Yu, H.; Zhu, Z.; Shen, F.; Wu, M.C.; Cong, W.M. Pathobiological features of small hepatocellular carcinoma: Correlation between tumor size and biological behavior. J. Cancer Res. Clin. Oncol. 2011, 137, 567-575. [CrossRef] [PubMed]

23. Asaoka, Y.; Tateishi, R.; Nakagomi, R.; Kondo, M.; Fujiwara, N.; Minami, T.; Sato, M.; Uchino, K.; Enooku, K.; Nakagawa, H.; et al. Frequency of and predictive factors for vascular invasion after radiofrequency ablation for hepatocellular carcinoma. PLoS ONE 2014, 9, e111662. [CrossRef] [PubMed]

24. Montasser, M.F.; Shaker, M.K.; Albreedy, A.M.; Montasser, I.F.; El Dorry, A. Risk factors for early intrahepatic distant recurrence after radiofrequency ablation for hepatocellular carcinoma in Egyptian patients. J. Dig. Dis. 2014, 15, 676-683. [CrossRef] [PubMed]

25. She, W.H.; Cheung, T.T. Bridging and downstaging therapy in patients suffering from hepatocellular carcinoma waiting on the list of liver transplantation. Transl. Gastroenterol Hepatol 2016, 1, 34. [CrossRef] [PubMed]

(C) 2019 by the authors. Licensee MDPI, Basel, Switzerland. This article is an open access article distributed under the terms and conditions of the Creative Commons Attribution (CC BY) license (http://creativecommons.org/licenses/by/4.0/). 